University at Albany, State University of New York

Scholars Archive

\title{
The Professional Identity of Three Innovative Teachers Engaging in Sustained Knowledge Building Using Technology
}

Jianwei Zhang

University at Albany, State University of New York, jzhang1@albany.edu

Barbara Vokatis

SUNY Oneonta

Follow this and additional works at: https://scholarsarchive.library.albany.edu/etap_fac_scholar

Part of the Education Commons

\section{Recommended Citation}

Zhang, Jianwei and Vokatis, Barbara, "The Professional Identity of Three Innovative Teachers Engaging in Sustained Knowledge Building Using Technology" (2016). Educational Theory and Practice Faculty Scholarship. 22.

https://scholarsarchive.library.albany.edu/etap_fac_scholar/22

This Article is brought to you for free and open access by the Educational Theory and Practice at Scholars Archive. It has been accepted for inclusion in Educational Theory and Practice Faculty Scholarship by an authorized administrator of Scholars Archive. For more information, please contact scholarsarchive@albany.edu. 


\title{
The Professional Identity of Three Innovative Teachers Engaging in Sustained Knowledge Building Using Technology
}

\author{
Barbara Vokatis ${ }^{a}$, Jianwei Zhang ${ }^{b}$

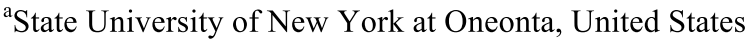 \\ ${ }^{\mathrm{b}}$ State University of New York at Albany, United States \\ Article received 30 October / revised 15 February / accepted 16 February / available online 14 April
}

\begin{abstract}
Diffusing inquiry-based pedagogy in schools for deep and lasting change requires teacher transformation and capacity building. This study characterizes the professional identity of three elementary school teachers who have productively engaged in inquirybased classroom practice using knowledge building pedagogy and Knowledge Forum, a collaborative online environment. Grounded theory analysis of teacher interviews, supplemented with field observations, highlights five distinctive features of the teachers' identity: (a) Teachers as professional knowledge builders to explore new visions of teaching for continual improvement of knowledge building; (b) Teachers as co-learners to form symmetrical relationships with students so they can take on the highest level of responsibility; (c) Teachers as problem-solvers and barrier-breakers holding a proactive stance toward the contexts of practice; (d) Teachers as members of a professional community that encourages collaboration, innovation, and continual improvement; and (e) An empowering relationship with the Principal who supports teacher innovation and collaboration.
\end{abstract}

Keywords: teacher identity; knowledge building; inquiry learning; problem-centred pedagogy; technology 


\section{Introduction}

Current education reforms require teachers' capacity to incorporate authentic inquiry practices by which students construct powerful explanations and designs to address authentic problems (National Research Council, 2012). While various professional development resources are initiated to help teachers understand inquiry-based teaching strategies and technologies, the knowledge of teaching methods does not suffice to become a responsive and thoughtful inquiry-based educator (Fairbanks, Duffy, Faircloth, Ye, Levin, Rohr, \& Stein, 2010). The complexity of teaching demands that teachers develop adaptive expertise (Bransford, Darling-Hammond, \& LePage, 2005) and capacity to engage in wise and collaborative improvisation in response to students' evolving thinking and changing needs (Little, Lampert, Graziani, Borko, Clark, \& Wong, 2007; Sawyer, 2004). Therefore, good inquiry-based teaching cannot be reduced to prescriptive techniques, but comes from the identity of the teacher as a whole person (Palmer, 1997). This aspect of teaching gives educators a sense of their selfhood as dynamically connected with their students and subject areas, allowing them to have a clear vision of themselves and what is important for them to accomplish with children (Duffy, 2005), and to have the soul and agency to overcome obstacles as they constantly look for ways to respond to the needs and thinking of students (Fairbanks et al., 2010). The goal of this study is to provide a detailed account of the professional identity of three elementary school teachers who have been working persistently and productively with knowledge building pedagogy and technology, one of the most influential computer-supported collaborative inquiry programs to cultivate creative knowledge work among students (Scardamalia \& Bereiter, 2006). Our conceptual framework guiding this study is two-fold, focusing on teacher identity and knowledge building, respectively.

\subsection{Conceptualizing teacher identity}

The concept of teacher identity refers to how teachers identify themselves as teachers, including who they are as professionals, and who they strive and are empowered to become in a constant process of reflecting on their practices and experiences. Teacher identity is not a static entity; a teacher constantly constructs and develops a reflective sense of self through looking into his or her practice and life of teaching, as a mirror (Palmer, 1997). Teachers teach who they are (Clandinin \& Huber, 2005; Palmer, 1997); a teacher's identity is associated with his or her distinctive set of practices (Gee, 2001), such as inquiry-based teaching. In this sense, teacher identity is intertwined with teacher practices (Enyedy, Goldberg, \& Welsh, 2005). Teachers' professional identity arises out of their various types of teaching practices across contexts in which they construct holistic views of themselves in relation to students, colleagues, professional purposes, and circumstances of teaching (Beijaard, Meijer, \& Verloop, 2004; Dillabough, 1999; Olsen, 2008). In this sense, teacher identity differs from teachers' specific practices and functional roles: their roles are associated with specific jobs and skills of teaching while teacher identity is a more personal entity that indicates how one identifies himself or herself as a teacher (Mayer, 1999).

Our conceptualization of identity draws heavily on the work of Gee (2001) and other researchers who highlight a number of important characteristics of teacher identity (Beijaard et al., 2004; Connelly \& Clandinin, 2000; Rodgers \& Scott, 2008; Sfard \& Prusak, 2005). First, teacher identity is a constantly undergoing process in which a person interprets and reinterprets oneself as a certain kind of person and is also recognized as a certain kind of person in a particular context (Gee, 2001). It is not limited to answering the question "Who am I at this moment?", but also entails answering the question: "Who do I want to become?" (Beijaard et al., 2004). Thus, teachers need to constantly explore and reflect on who they are as professionals based on their experiences (Antonek, McCormick, \& Donato, 1997; Brooke, 1994) and actively look for new ways to define their professional work to approach important educational issues (Coldron \& Smith, 1999). They frame and develop who they are through reflective story telling about what they strive for and do as teachers: "stories to live by" that are shaped by the past and project into their ongoing lives and works (Connelly \& Clandinin, 2000). 
As its second feature, teacher identity is shaped by multiple contexts of teaching practices (Beijaard et al., 2004; Rodgers \& Scott, 2008). Contexts entail larger socio-cultural-historical processes that influence teachers' identity (Varelas, House, \& Wenzel, 2005), personal histories that alter teachers' beliefs and values, the culture of the institution, including the history of the institution, and values held by its administrators and other members. Through reflecting on their practice and identity, teachers "become more in tune with their sense of self and with a deep understanding of how this self fits into a larger context which involves others" (Beauchamp \& Thomas, 2009, p. 182).

Therefore, teacher identity involves sub-identities that are reflected in their relationships with peer teachers, students, administrators, and other members of their school communities (Beijaard et al., 2004). Examining a teacher's identity requires understanding how the teacher forms certain relationships with his or her students, peer teachers, and school administrators and positions himself or herself toward the context such as the curriculum, school policy, and physical school environment. Social relationships are crucial to identity, because to have an identity one must be recognized as a particular "kind of person" by others (Gee, 2001). How a teacher identifies himself or herself stems from the nature of social interactions the teacher has with his or her peers and others (Dillabough, 1999). Within multiple contexts, a teacher forms multiple relationships that bring forth multiple aspects of himself or herself (Gee \& Crawford, 1998; Rodgers \& Scott, 2008). Teacher identity is co-constructed "through engagement with others in cultural practice" (Smagorinsky, Cook, Moore, Jackson, \& Fry, 2004, p. 21). A teacher's identity influences how he or she negotiates his or her role in relation to administration, curriculum and students, and these relationships further influence the teacher's identity (Enyedy et al., 2005). In an autographic study, Brooke (1994) also found that becoming a professional teacher involves interacting with others' views. The conflict between one's own images of teaching and peers' expectations of what makes a professional teacher may lead to deep reflection on identity (Volkmann \& Anderson, 1998).

A final, critical feature of teachers' identity pertains to their agency and voice to shape their own professional paths (Rodger \& Scott, 2008). Teachers' professional identity develops as a result of the negotiation between given factors, such as existing social structures and policies, and teachers' agencydriven participation and engagement with educational resources and ideas (Coldron \& Smith, 1999). Agency is the empowerment to act (Holland, Lachicotte, Skinner, \& Caine, 1998). A teacher with agency not only knows how to act within the existing world of education but also acts upon and remakes the world in line with his or her vision. Such agency results from a teacher's realization of his or her identity (Beauchamp \& Thomas, 2009; Parkinson, 2008) and further drives his or her continual efforts to explore and form new identifies as he or she goes beyond current classroom practices.

In this study, we investigated the identity of inquiry-based teachers who have engaged in knowledge building pedagogy and technology as a school-wide innovation implemented over a decade. School-based professional development has been provided to support their ongoing reflection on their knowledge building practices in classrooms as well as what it means to be inquiry-based, knowledge building teachers. This study examines how the teachers reshape their identity through their long-term engagement in knowledge building practices. In line with the above conceptualization, we analyse their reflective stories about what they strive for through their unique set of practices (Gee, 2001), supported by their relationships with their students, colleagues, and the Principal.

\subsection{Teacher identity in inquiry-based, knowledge building communities}

With schools increasingly incorporating problem-centred, inquiry-based pedagogy to develop student productive knowledge and higher-order competencies (e.g. creativity, collaboration, and other $21^{\text {st }}$ century competencies), research on teacher learning and development needs to understand the professional identity of teachers who are dedicated to implementing and sustaining inquiry-based learning in their practice. The literature on inquiry-based, collaborative learning suggests various new roles to be played by the teacher: a designer, facilitator, mentor, modeller of authentic inquiry processes, and a partner or co- 
learner who co-engages in the inquiry processes with his or her students, valuing students as collaborative contributors while fostering their ownership and agency (Belland, Glazewski, \& Richardson, 2008; Brush \& Saye, 2000; Crawford, 2000; Hjalmarson \& Diefes-Dux, 2008; Hmelo-Silver \& Burrows, 2006; Lunn \& Solomon, 2000; Mills, 2014; Tabak \& Baumgartner, 2004; Zhang \& Sun, 2011; Zhang, Hong, Scardamalia, \& Morley, 2011). However, existing research on teacher learning to support inquiry-based classroom innovation primarily focuses on teacher knowledge and practices (see Fishman, Davis, \& Chan, 2014 for a review), with scarce research efforts centring on the professional identity of teachers who are innovative, persistent, and productive in implementing inquiry-based learning (Enyedy et al., 2005). Teacher identity aligned with inquiry-based pedagogy allows teachers to pursue and persist in implementing adaptive, responsive teaching (Duffy, 2005; Fairbanks et al., 2010) and continually inventing new and more productive practices (Davis, 2006). Therefore, in order to better understand teacher identity in support of inquiry-based pedagogy, the present study examines the professional identity of teachers who are deeply engaged in continuous classroom innovation using knowledge building pedagogy and technology (Scardamalia \& Bereiter, 2006).

The knowledge building pedagogy belongs to the larger family of problem-centered, inquiry-based learning programs, with a particular focus on designing inquiry following authentic knowledge creation processes (Scardamalia \& Bereiter, 2006). Beyond project-based inquiry that requires students to address pre-defined problems and tasks, knowledge building pedagogy approaches inquiry as progressive problem solving achieved by sustained collective discourse: Students identify new and deeper problems as old ones are addressed, driving sustained advancement of collective understandings. Students work as a knowledge building community to engage in such sustained inquiry and discourse and collectively advance the "state of the art" of their community's collective knowledge (Scardamalia \& Bereiter, 2006). They identify deepening problems of understanding, develop and contribute ideas to a public space, engage in collaborative discourse and experimentation, and use a wide variety of resources to advance their ideas. A networked knowledge building environment-Knowledge Forum, formerly known as CSILE (Computer-Supported Intentional Learning Environment) - has been developed to support knowledge building discourse and processes (see Scardamalia \& Bereiter, 2006). Knowledge Forum provides a collective knowledge space that gives student ideas a public, permanent representation. Students contribute diverse ideas to ongoing conversations and collectively advance the ideas through constructive criticisms, mutual build-on, and progressive problem solving, with new and deeper challenges identified as their understanding is advanced (Bereiter, 2002). Specifically, students record ideas in views (workspaces). These workspaces correspond with their focal goals. Students write notes in these views in order to contribute their ideas, data, and related information using text and graphics. Knowledge Forum has supportive features for knowledge-building discourse that allows students to co-author, build on, and annotate notes. Students can also create reference links with citations to existing notes, as well as add keywords and create rise-above notes to summarize and advance their discussions (Scardamalia, 2004). Knowledge Forum scaffolds additionally support both individual contributions and learning as well as collaboration, turning over to students higher-level knowledge processes. Customizable scaffolds are designed to support various knowledge processes, such as using the sentence starters "My theory," "I need to understand," "This theory cannot explain," "A better theory," and "Putting our knowledge together" to support theory development (Scardamalia, 2004).

Knowledge building is a dynamic, social activity system in which students interact with diverse people and ideas to advance their collective knowledge. The social and cognitive complexity of this process requires a principle-based, adaptive approach to classroom design and practice, which differs from procedure-based inquiry designs that require students and their teacher to work on pre-defined project tasks following pre-scripted procedures and timelines (Zhang et al., 2011). Knowledge building in classrooms is guided by a set of 12 knowledge building principles, including epistemic agency, real ideas and authentic problems, continual idea improvement, collective responsibility for community knowledge, knowledge building discourse, and constructive use of authoritative sources (Scardamalia, 2002). Epistemic agency allows students to set goals for learning, initiate and sustain knowledge advancement, and engage in higherlevel knowledge work normally left to the teacher. The principle of real ideas and authentic problems allows 
students to identify problems that stem from their curiosity and efforts to understand the world. The principle of continual idea improvement treats ideas as ever improvable, not simply rejected or accepted. The principle of collective responsibility for community knowledge places a responsibility on all participants for contributing to community goals and advancing community knowledge, not only individual learning. The principle of knowledge building discourse asks students to engage in discursive practices whose goals are not only to share, but also to transform and advance knowledge. The idea behind the principle of constructive use of authoritative sources is accessing and critically evaluating sources of information. Students use these sources to support and refine their ideas, not just to find "the answer." The 12 principles and corresponding support in Knowledge Forum create affordances for knowledge building in a community.

In a knowledge building initiative focusing on a deep curriculum area(s), teachers and their students co-construct goals of inquiry based on progressive questions from students, and design knowledge building activities in light of the principles. Resources and supports are in place for teachers to share lesson examples and reflect on knowledge building processes using real-time analytic data about idea contributions and social interactions. Teachers have utilized the automated feedback generated by the automated tools for the purpose of facilitating reflection and improving practice. This principle-based approach gives teachers a high-level ownership over classroom practice and innovation, so they can continually improve and adapt classroom designs and pedagogical understandings to enable increasingly productive knowledge building experiences among their students (Chan, 2011; Zhang et al., 2011).

This study examines the professional identity of a group of teachers from an elementary school that has been implementing knowledge building pedagogy and technology for more than a decade. Our previous analysis based on rich data collection over eight years demonstrated the teachers' continual improvement of inquiry practice as reflected in student active and collaborative engagement in knowledge building (Zhang et al., 2011). Enabling such sustained innovation and improvement, the teachers formed into a professional knowledge building community themselves to discuss advances and challenges, co-design and test classroom designs, reflect on their practice based on data collected, and continually deepen their understanding of knowledge building principles that inform new possibilities of improvement (Zhang et al., 2011). The purpose of this study is to investigate the professional identity of these teachers in the context of knowledge building classrooms. Our research question asks: What characterizes the professional identity of these teachers who are dedicated to and capable of sustained innovation using knowledge building pedagogy and technology?

\section{Method}

This case study was conducted as a part of a larger research initiative to examine the enactment of knowledge building as a principle-based innovation at an elementary school over a decade: The Dr. Eric Jackman Institute of Child Study Laboratory School in Toronto (Zhang et al., 2011). The school was established in 1926, partly inspired by the work of John Dewey. It enrols approximately 200 students from Nursery (Pre-K), Junior Kindergarten, Senior Kindergarten, to Grade 6, with 22 students on average per class. Most families come from a middle class background and pay a tuition fee. As a laboratory school, Jackman ICS has been involved in initiating and disseminating new ideas related to improving education. It makes daily contributions to teacher training, providing internship opportunities for graduate students in the programs of child development and education. Knowledge building pedagogy and CSILE/Knowledge Forum were first introduced in 1994, tested by a few classrooms between 1996-2000, and adopted across the entire school since 2000.

For the larger study, we analysed the knowledge building initiatives facilitated by the teachers over eight years focused on core scientific themes as well as social topics. The analysis of student online discourse in Knowledge Forum demonstrated increasing levels of collaborative knowledge advancement 
associated with years of teachers' experience. Teacher interviews, reflection journals, and on-site observations helped to elaborate the teachers' efforts and school conditions. Qualitative analysis revealed that the teachers continually and collaboratively worked on improving their practice and deepening their understanding of knowledge building pedagogy. Through experimenting with new ideas and openly sharing them with other teachers, they developed adaptive expertise (Crawford, Schlager, Toyama, Riel, \& Vahey, 2005; Zhang et al., 2011). The present study re-analysed the interviews with three teachers to understand their professional identity. These teachers were chosen because they represented different grade levels, had the most extensive experience with knowledge building pedagogy at their school, and were often requested to provide mentoring support to other teachers from the international network of knowledge building communities. The teachers included Raphael, a male teacher teaching Grades 4-6; Zanna, a female teacher teaching Grades 2-3; and Cadence, a female teacher teaching Kindergarten (these are pseudonyms). All the teachers were middle-aged and had over five years of experience in teaching. Each interview took approximately 30 minutes, focusing on how the teachers approached and improved their classroom practices to better support knowledge building. Example interview questions included: How do you see your role as a teacher? What are the three most important qualities you would like to develop in your students? What are the major things you do to develop these qualities? What have been your three most important improvements in your teaching in the past years? In what way do you see your colleagues/Principal as supportive of your efforts for seeking innovation in teaching? The analysis of identity was mainly based on the interviews in which the teachers reflect on who they are and what they strive for. The analysis was contextualized by observational records of the teachers' classroom practices, which were systematically analysed for the larger project.

The interviews were fully transcribed, and then analysed using a grounded theory approach (Strauss $\&$ Corbin, 1998). The grounded theory approach suits the subject of this research because, although teacher professional identity has been investigated in the literature in light of theories of identity, inquiry-based teachers with high levels of innovativeness have never been examined for this purpose. We also argue that incorporating already existing ideas from literature regarding what constitutes teacher identity not only does not "compromise methodological "purity" (Dunne, 2011, p. 113), but "can actually enhance rigor" (p. 113). The literature review provides a clear rationale for the study and a specific research approach (Coyne \& Cowley, 2006; McGhee, Marland, \& Atkinson, 2007). Secondly, it is helpful in contextualizing the study (McCann \& Clark, 2003), provides the researcher with an aim (Urquhart, 2007), and makes known how the phenomenon has been researched (Denzin, 2002; McMenamin, 2006). Thirdly, it is helpful in developing 'sensitising concepts' (Coffey \& Atkinson, 1996; McCann \& Clark, 2003) and promoting "clarity in thinking about concepts and possible theory development" (Henwood \& Pidgeon, 2006, p. 350).

Following procedures of grounded theory analysis, the first author first read and re-read the interview transcriptions, and created open codes that reflect specific features of the teachers' identity. These codes were then categorized into primary themes that include subthemes to capture prominent features of the teachers' professional identity in connection with their knowledge building practice. The creation of the themes was informed by teacher identity and knowledge building as our two-fold conceptual framework and by the features of teacher identity reviewed in the beginning of this article while remaining open to possible new aspects of teacher identity in the contexts of knowledge building. The two authors then co-reviewed the open codes and initial themes and subthemes and discussed any disagreements. For example, several raw codes such as classroom as a community of researchers, teacher as an authentic co-learner, and faith in students developed into the following subtheme: "Teacher as a co-learner: Sustaining students-driven inquiry through symmetrical teacher-student interactions in which the teacher is not an intellectual authority but a co-learner." This subtheme became then the core aspect of the following theme: "Teachers as co-learners: Forming symmetrical relationships with students so they can take on the highest level of responsibility for learning and knowledge advancement."

In grounded theory analysis, the degree of agreement between researchers is not as important as "the content of disagreements and the insights that discussion can provide for refining coding frames" (Barbour, 2001). In addition, we employed a reflexive approach to the analysis to ensure reliability and validity (Barry, 
Britten, Barber, Bradley, \& Stevenson, 1999). Schwandt (1997) specifies reflexivity as two-fold. The first aspect involves being part of the setting, context, and a phenomenon being researched. The second is "[a] process of self reflection of one's biases, theoretical predispositions, preferences and so forth" (p. 135). We used reflexivity "to move us outward to achieve an expansion of understanding" (Barry, Britten, Barber, Bradley, \& Stevenson, 1999, p. 30). We were reflexive not only by keeping reflexive diaries and recording analytic decisions in memos, but also by being reflexive about every decision we made (Mason, 1996). In addition, as a team, we engaged in group reflexivity, making sure that there was a dialogue between our individual reflexivities and our group reflexivity (Barry et al., 1999). In negotiation of our ideas, we developed a dialectic that improved our thinking. That is, by sharing and negotiating our thinking and differences, we thought through our positions and justified them, and if an argument could not be justified, it became apparent that it was weak (Barry et al., 1999). The themes and subthemes were then refined and further validated through relating and comparing the themes, checking data against the themes, and triangulating the identified themes with data from the teachers' journals and field observations. The refined themes and subthemes are elaborated in Results.

\section{Results}

The data analysis identified five overarching themes - each involving a number of subthemes - that characterize the professional identity of the knowledge building teachers. These themes are summarized in Table 1 and elaborated below.

Table 1

Themes and subthemes that characterize the identity of the knowledge building teachers

Theme Subtheme

Teachers as professional knowledge builders teaching as ever improvable to open new possibilities for student knowledge building and development to explore new visions of teaching: Viewing

A vision of teaching for lifelong learning and whole child development (e.g. intellectual curiosity, creative problem solving, caring and collective responsibility, open-mindedness) beyond curriculum coverage;

A strong belief that pedagogical knowledge and practice need to be continually built and refined to foster increasingly productive knowledge building;

An adaptive, open approach to teaching so new classroom arrangements, procedures, and technologies are continually tested and flexibly adapted and integrated in the service of knowledge building and inquiry.

Teachers as co-learners: Forming symmetrical relationships with students so they can take on the highest level of responsibility for learning and knowledge advancement

Teacher as a co-learner: Sustaining students-driven inquiry through symmetrical teacher-student interactions in which the teacher is not an intellectual authority but a co-learner;

Student agency: Honouring students as research team members who are responsible for proposing goals and ideas for research, building and assessing theories, and designing experiments and other activities; Collective engagement: Respecting and engaging each student as a contributive member of a knowledge building community;

Students-driven discourse: Striving for spontaneous, idea-centred conversations co-improvised by all community members in both faceto-face and online environment-with the teacher as one of them. 
Teachers as problem-solvers and barrierbreakers: Holding a proactive stance toward the contexts of practice to address challenges, constraints, and barriers for continual improvement

Teachers as members of a professional community that encourages collaboration, innovation, and continual improvement: Building collaborative relationships with colleagues to share, discuss, design, and reflect on innovative classroom practices

An empowering relationship with the Principal: Perceiving the Principal as both a leader and a professional colleague who supports teacher innovation and collaboration
A commitment to developing context-adaptive strategies to make knowledge building possible and effective across age groups and classroom settings;

A barrier-breaking attitude to address practical challenges such as time limit and technical problems through flexible and integrated arrangements.

A shared focus on continual improvement and invention in teaching beyond routine procedures;

Conviction that improvement is achieved through collaborative efforts; Continual, professional knowledge building discourse that supports collaborative problem solving and ideation in teaching;

Boldness to share and reflect on both successes and failures; Confidence in accepting risk-taking as inevitable in experimenting with new approaches;

A hybrid identity that integrates practice with research for continual improvement of teaching.

Democratic, supportive, and professionally centred relationship with the Principal as crucial in all teachers' undertakings;

Empowerment to innovate resulted from the relationship in which collaborative experimentation and risk-taking are valued and encouraged.

\subsection{Teachers as professional knowledge builders to explore new visions of teaching: Viewing}

\section{teaching as ever improvable to open new possibilities for student knowledge building and development}

As a crucial aspect of who they are and mean to achieve, the teachers' comments in the interviews reveal a perception of themselves as professional knowledge builders who are committed to explore innovative visions of teaching to open new possibilities for student knowledge building and development.

First, the focal teachers see themselves as teachers for whole child development and lifelong learning, not just to cover the curriculum. Specifically, they are committed to developing crucial qualities that go beyond curriculum content coverage, such as curiosity, intellectual thinking skills, creative problem solving, social caring, collective responsibility, and open-mindedness. They stress that these qualities are important for student development and further needed for students to engage in productive knowledge building.

Developing curiosity is one of the most important qualities that constitute who they are as young children's educators. Raphael (teaching grades 4-6) recognizes the limitation of the curriculum in stimulating children's natural curiosity that drives inquiry learning; thus, in his classrooms, he particularly encourages students to ask deeper and deeper questions and engage in curiosity-driven inquiry. Similarly, Cadence and Zanna (grades 2-3) mention the importance of exploring questions that are asked by children and of their interest. Specifically, they elaborate that this way of teaching, contextualized and situated in children's lives, is aligned with children's needs and curiosity, leading to active engagement and deep exploration, which is the essence of inquiry. As Zanna says, she wants to instil "a love of learning so that when they come to school they don't see the work of school as being just for school but they see that it is important for their life." At the same time, Zanna underscores that this attitude to teaching is a part of who she always was: "I really tried to hold onto it in the public school system, but to come back here and find everyone like-minded it has just brought me right back to the way children learn best, developmentally appropriate practice."

Curiosity, according to the teachers, as a tenet that stimulates desires to investigate something in depth, is vital in problem solving and nurturing an inquiring mind. Teaching how to solve problems also starts very early. It is in Kindergarten where children learn that problems can be solved with their efforts and 
that there are specific words and strategies that can help them. When problems are brought to the group, through conversation children find out how to solve them. Cadence, the Kindergarten teacher, stresses, "We talk a lot. We bring problems of understanding, social issues to the group... no matter what kind of problem it is, you can solve something piece by piece... you can bring it to the community and see that you aren't just addressing the small problem that came up or that conflict, you are actually figuring out how to figure out all conflicts." Zanna adds, "We have a class meeting every Friday where we sit in a circle and we talk about the week and one thing that kids can do is to raise up a problem they have." At the same time, Raphael underscores that major knowledge advancements may not be achieved all the time as he would hope, but at least he observes "the desire to go deeper" among his students as a result of their engagement in the inquiry activities.

Developing independence in thinking is another important part of what the teachers mean to achieve. Cadence mentions developing independence and open-mindedness in thinking very early in children's education: "I want them to be knowing that they can act independently; they don't need to have a teacher there, guiding them in the whole way, and telling them what they're doing is right or wrong." For Zanna, developing independence is also important: "I want the kids to rely on each other so they don't feel they need to come to me. I don't want to be centre of the class." Raphael stresses that he wants to instill in children a disposition of "seeking the information as opposed to children thinking that things have to come to them either from a teacher or a book."

Aligned with their commitment to growing care, curiosity, and independent thinking in their students, the teachers focus their role on creating a community of knowledge builders who share collective responsibility. The teachers stress collective responsibility that allows students to keep moving forward in their common pursuit of knowledge and hold each other accountable without the teacher stepping in all the time. Cadence mentions that her Kindergarteners already learn that being a part of a community entails certain behaviours, such as respecting everybody as a member of the community and valuing everyone's ideas. Zanna adds, "I want them to take responsibility for their actions, not to blame others or to say 'oh I didn't do it' but to make good choices and when they don't make good choices to admit to it." Raphael gives a specific example of such collective responsibility, "...the children will say 'you've been researching for two days and you haven't written anything on the database yet, we need to know what you've done. We've given you this time and you have to give us back some information' and so that completely changes the nature of the community it is very responsible and works as a unit and where they are leading it themselves."

To explore and achieve their vision of teaching, the teachers embark on a sustained, reflective journey to explore and build new knowledge about their profession. In the interviews, the teachers comment that they constantly rediscover what it means to be a knowledge building teacher. Their understanding of knowledge building pedagogy has been constantly evolving over time. In this process, they are all learners. Raphael made a comment that encapsulates this critical belief in rethinking, refinement, and improvement: "But five years from now, we can come back and say: 'I don't know what I was talking about then, and this feels like knowledge building!' So there is constant improvement. Just like ideas are improvable, the process of knowledge building is improvable.... You're constantly going deeper in what this means... None of us is the learned. We're all learners." Cadence adds: "I never try to think that worked really well, I'm going to do the same thing again. I always look for ways to improve my practice."

The teachers' comments on new advances they have made in their classrooms demonstrate their adaptive, open approach to teaching by which new classroom arrangements, procedures, and technologies are continually tested, flexibly adapted, and integrated to serve and strengthen knowledge building and inquiry. What these teachers have learned and experienced in this process further strengthens their identity as knowledge building teachers. For Zanna, continual testing of adaptive approaches is vital to her professional identity. She has experimented with various strategies to support student knowledge building discourse both in face-to-face interactions and in Knowledge Forum and found out that giving children the opportunity of recording their ideas in the online space creates the possibility to revisit the ideas later for further 
exploration. She expresses her thoughts in this regard, "...because we have the software, the questions live there and they do get answered."

Reflecting on his experimentations in the classroom, Raphael comments on the changes he has made to develop dynamic collaboration structures for knowledge building over three years. He began with collaboration in fixed small-groups in the first year, evolved to collaboration in interacting groups, and eventually to opportunistic collaboration among students based on emergent needs without fixed smallgroups. Analysis of the online discourse showed that increased connectivity and productivity among his students resulted from these changes (see Zhang, Scardamalia, Reeve, \& Messina, 2009; Zhang \& Messina, 2010). Raphael has also changed the way classroom conversations are organized; instead of scheduling them in advance, he decided to allow the conversations to emerge naturally, when children felt that they had something important to discuss. Similarly, the use of technology in his classroom has gone from teacherdirected tasks to trusting children and allowing them to decide if an idea or question is suitable and important for discussion, online or face-to-face. As all the teachers stress, such efforts to continually improve and innovate teaching is an important characteristic of who they are. As new notions and strategies of teaching continue to develop, the teachers further redefine their relationship with students in the classroom.

\subsection{Teachers as co-learners: Forming symmetrical relationships with students so they can take on}

\section{the highest level of responsibility for learning and knowledge advancement}

The focal teachers identify themselves as co-learners who honour students as research team members for collective knowledge building.

The teachers describe themselves as authentic members of the classroom community who co-engage in the knowledge building and problem solving processes with students. Raphael stresses his position: "We are a community of researchers in the classroom...I try to do things that I don't know the answer to so that it becomes an authentic KB [knowledge building] experience for me as well, so that I can say to the students I'm not exactly sure. Let's find out." Zanna adds, "I don't want to be centre of the class. I want to be another member of the community." Cadence also underscores this distinctive relationship that she creates in her classroom, saying: "You're not always the intellectual authority."

Perceiving themselves as co-learners leads to a more symmetrical relationship with students. They honour students as research team members who have the agency and capability of proposing goals and topics for research, building and evaluating theories, designing experiments, and forming collaborative groups. Raphael underscores this point with enthusiasm: "Imagine if a child feels that from the very beginning they could add by connecting things in an interesting way... they might be adding a new perspective, a new theory." The teachers trust that children can take on high-level responsibility in the classroom to generate deepening questions and ideas. They communicate this trust to their students during activities and encourage children to ask questions that would direct and deepen their collective inquiry. As Zanna notes: "Children could put their ideas in the pocket if you want to talk about. So the students have more agency in what's happening in the [knowledge building] talks. It's not me deciding, but they identify 'we want to talk about this, ' we want to put the view up on the wall.' Whatever they want to do."

The symmetrical relationship with students is reflected in students-driven, open-ended discourse in the classroom and on Knowledge Forum, which are not pre-scripted by the teacher but co-improvised by all community members - with the teacher as one of them. The teachers comment on the importance of respecting diverse ideas. They model their respect of student ideas in the classroom and further create a community that respects diverse voices from all members. The diverse ideas are treated as the driving force to deepen classroom discussions. Cadence underscores her openness to follow children's deepening questions and ideas and let them explore these questions for sustained inquiry and discourse. She describes how children's interest in how trees breathe led to a three-month investigation: 
It was the very first day of school. I thought it would be interesting to do a study of trees. ... And I tried to think where it might go...Every year in the fall, [students] bring in different colours of leaves, they look at the shapes...I think I would probably be talking about leaves and colours and maybe get to the cells... So the very first day, I started asking kids what they knew about trees. And as they told me about different parts of trees, I drew on a piece of chart paper. So someone said branches...twigs...and then a child said: "lungs." And I just stopped... It's such a clear way that puts me in an interesting position. So I said: "Where would I put the lungs?" And she said: "I don't know. They have to breath, don't they? They're alive." And for the next months, we looked into how trees breathe. That's how it caught children's interests in the class. ... And it was amazing to notice that you don't have to have these arbitrary barriers, that you can study so many things: do literacy and drama, deep thinking, and specific experiments... So for me it was a huge moment as a teacher to realize just how much you can blast open the possibilities of depth and time.

In the above example, when one of the students mentioned lungs as a part of a tree, the teacher did not just say that trees do not have lungs but treated this as a real and meaningful idea, which has the potential to stimulate investigations of how trees breathe and live. Through acknowledging the student's idea and asking a question "Where would I put the lungs?" the teacher helped the students to recognize an authentic problem, leading to a deep inquiry beyond the teacher's imagination.

In addition to their trust in student agency and capability to generate questions and ideas for deep inquiry, the teachers further encourage students to take on high-level responsibilities that are usually enacted by the teacher in traditional classrooms. These include giving input to high-level decisions about what needs to be studied, through what activities, who will do what, when, and how the online discussion space should be structured and used. The teachers all stress that it is important to encourage children to propose specific problems for discussions as opposed to following teacher-set topics and schedules. The example coming from the classroom of Raphael is particularly striking. At the beginning, he simply planned and scheduled knowledge building talks - a structure co-developed by the teachers to facilitate interactive discourse focusing on advancement of ideas beyond information sharing (see Zhang et al., 2011). Then, he hung pockets in the classroom to encourage students to drop a note when they have important problems or knowledge advances to talk about. Through this and other changes, the knowledge building talks in his classroom have become much more spontaneous and organic, with continual improvement of ideas as the focus. In our classroom observations, we captured chunks of metacognitive discourse embedded on the ongoing classroom dialogues, which focus on issues such as: Are we making progress? What are the areas that need more research? What kinds of information should be recorded in Knowledge Forum? Student input to these questions leads to collective decisions about how the community should focus and refine their knowledge building work in the next phase.

The focal teachers see Knowledge Forum as an enabler for the shift of high-level responsibility to students. For example, Zanna values the use of Knowledge Forum to support sustained discourse and further make students' questions and progress visible for reflection. The software provides a space where "the questions live there and they do get answered." She expresses that before the use of Knowledge Forum, it was hard to trace which questions were answered. With Knowledge Forum's scaffolds, marking questions using "I need to understand" and theories using "My theory" and "A better theory," both teachers and their students can trace progress in addressing progressive questions and find areas that need deeper contributions, assisting collective decision making about unfolding directions and deeper actions.

While all three teachers emphasize the importance of a symmetrical relationship with their students, their personal styles vary. Zanna prefers to be a quiet speaker in the classroom. Raphael emphasizes that it is OK to intervene in a classroom discussion actively when needed, such as to recall and model the rules of contribution. 


\subsection{Teachers as problem-solvers and barrier-breakers: Holding a proactive stance toward the}

\section{contexts of practice to address challenges, constraints, and barriers for continual improvement}

Developing innovative practices in line with their visions of teaching require the teachers to face and address a range of challenges and barriers resulting from the contexts, such as time limit and school schedule, subject area limitations, age differences, and technology malfunction. Instead of being defeated by the challenges and barriers, the teachers become active problem-solvers and barrier-breakers.

While facing various challenges, the teachers have developed adaptive strategies to make knowledge building possible and effective across student age groups and classrooms, and they speak about these efforts as a part of who they are. As they strive to engage students of all ages in knowledge building, they need to develop adaptive ways of addressing the challenge of developmental differences. For younger students, the teachers especially focus on modelling tenets that are foundational for knowledge building, such as developing respect for others and different perspectives in order to adapt knowledge building principles to younger students. Cadence provides the support when she models how children should respectfully converse with each other, "I try to model a lot of my expectations for the children. So when we sit on the carpet, I don't sit on the chair...I think it's an important thing for me because I'm at their level... I hope I'm showing what kinds of comments, what kinds of questions have value for the whole group, and that, again, every voice needs to be heard." Such modelling does not need to be as intensive for older students. But Raphael underscores that while he strives to be just a member of the community, he never forgets about his modeling role, "...we are still modelling for children."

Another significant challenge the teachers have encountered is how to foster deep inquiry in different subject areas within typical time constraints. The teachers comment on a strategy they have developed to integrate different subjects into a sustained knowledge building initiative that addresses core contents of all the areas for integrated understanding. One of the most striking examples comes from Cadence who integrated several subjects under one big topic: Trees and how they breathe. She says, “...you can study so many things: do literacy and drama, and deep thinking, and specific experiments, every kinds of learning we want the children to do, you can actually do as one topic, because if it's a good topic, like trees and how they breathe, it is so rich, there're so many directions you can go." Efficiently integrating different subjects allowed the teachers to reallocate the time needed for each subject while further fostering the connected understandings among their students.

The intensive use of Knowledge Forum and other technology tools also requires the teachers to solve emergent problems related to technology use. The teachers comment on their constant experimentations to find meaningful ways to use technology for knowledge building and address issues of unproductive technology use. Raphael shared a story that a few of his students once refused to write on Knowledge Forum. By sitting down to listen to the students' concerns, he realized that the problem resulted from his procedural use of Knowledge Forum: Students were assigned to write online based on a preset schedule when they might not have deep ideas to contribute. Raphael made a change to encourage students to use the technology only when it is necessary, focusing on contributing important ideas instead of simple facts from books. Doing so helped to increase student engagement. He then reflected on what this struggle taught him, "So we have to really be careful of how we use the technology, that is not for the sake of technology. It has to be for the sake of knowledge building."

In terms of technological reliability, the teachers also need to learn to solve various technical problems themselves (e.g. Internet connection, forgetting passwords) due to the lack of a full time technology support specialist. They treat this challenge as an opportunity to model to children how problems can be solved and create alternative arrangements when technology does not work. Raphael stresses his persistent and proactive approach to solving problems with a "strong stomach." He says: "It puts you in a role where you have to be happy all the time with technology, and that's a lot of work. The children are watching you. They could give up easily, because the frustrations sometimes are huge. So we need always to be able to be flexible... it's about saying 'oh ok that's not working, let's do this over here...." 
Even at this laboratory school, one that has a supportive context for innovative classroom practices, the teachers experience challenges and struggles that they have to address in order to effectively implement knowledge building in their classrooms. Working collaboratively as a community helps them to share and address the challenges with mutual social support.

\subsection{Teachers as members of a professional community that encourages collaboration, innovation,}

and continual improvement: Building collaborative relationships with colleagues to share, discuss, design, and reflect on innovative classroom practices

Teachers' innovative collaboration with colleagues and considering themselves as not only teachers but also researchers is another major aspect of who they are as professionals.

The teachers see themselves and their teaching as a part of a professional community of teachers they work with. As Zanna says, "...everyone here is so interested in their teaching and improving it." Furthermore, all teachers underscore that forming such a professional group is crucial to innovation and improvement of their teaching. Raphael comments: "It creates an environment where you say something and even by just talking about it you are improving your understanding." Cadence adds, "Anytime I have an idea, a question and I want to connect with another class or another teacher you pretty much have people who are willing to go ahead and do it."

Moreover, conducting professionally oriented discourse at weekly knowledge building meetings, which supports their collaborative problem solving and formation of new ideas, shapes who they are as professionals. At the meetings, they exchange their classroom designs, insights, and challenges, ask questions, and continually develop better understanding and strategies for deeper and more productive knowledge building. Raphael stresses, “...each one of these [meetings] has completely changed me, my practice, you can, we all know, you can create a KB [knowledge building] environment and not be a knowledge-builder yourself. And to truly understand you need to be immersed in a KB experience yourself." They also stress that this community, which strives for excellence in teaching, is open to sharing both successes and failures. Such freedom and boldness in terms of talking about both successes and failures comes from the teachers' shared belief that risk-taking is inevitable in experimenting with new approaches that lead to the improvement of teaching practice. In this community, as Zanna underscores, "There is not that sort of pretending that everything is going great. People bring their problems up and admit when things aren't going well."

These teachers also identify themselves as both teachers and researchers and stress that researching their own practice, as well as working with other researchers, is a critical component of good teaching that promotes innovation, refinement, and change. Raphael elaborates on this important connection between teaching and researching, "The researcher part informs the teaching and the teaching informs the researcher part of me." Zanna sums up, "For me research goes along really well with teaching ... good teachers constantly reflect on their teaching and think about how to improve it... It is just a natural part of good teaching."

\subsection{An empowering relationship with the Principal: Perceiving the Principal as both a leader and a professional colleague who supports teacher innovation and collaboration for continual improvement}

The focal teachers develop a supportive relationship with the Principal who is professionally instead of administratively oriented. Through weekly knowledge building meetings and informal ongoing interactions, the teachers share with the Principal and other colleagues their teaching expertise, ideas and designs, understanding of children's development and needs, and vision of innovative teaching. The Principal participates in the professional dialogues and gives her input. Cadence comments on this sharing, 
"If you have an idea, you present it to her [the Principal] and it makes sense to her, she is going to back you up. She may have questions about it and ask you to think about it in a slightly different way that has more value, but she is really going to support it." Zanna underscores that she gains support from the Principal to sustain her innovative practices, saying: "She is a fabulous leader and it allows me to teach the way I want to teach, be innovative, and reflect on my practice." Raphael expresses the essence of this relationship, "We are incredibly empowered. We are given a lot of support, but with that comes a huge amount of responsibility as well."

\section{Discussion}

The present study sought to illuminate the professional identity of three teachers who have been working persistently and productively with knowledge building pedagogy and technology. While the existing literature on teachers in inquiry-based settings focuses on investigating teacher practices and strategies to facilitate collaborative inquiry and the interplay with teacher knowledge, beliefs, and goals (see Fishman et al., 2014 for a review), this study is the first to examine the new professional identity of teachers who have engaged in sustained knowledge building pedagogy and classroom innovation for multiple years. Our interview data captured their reflective story telling about what they do and mean to achieve as teachers (Connelly \& Clandinin, 2000). As the review of literature suggests, teachers constantly construct and refine their reflective sense of self through looking into their practice of teaching (Antonek, McCormick, \& Donato, 1997; Brooke, 1994; Palmer, 1997). Through their long-term engagement in knowledge building pedagogy and technology, as a distinctive set of practices (Gee, 2001), the focal teachers in this study develop new understandings of who they are and what it means to be inquiry-based knowledge building teachers. Specifically, the analysis elaborates five important distinctive facets of the teachers' identity that fits into the larger context of practice (Beauchamp \& Thomas, 2009) involving their students, colleagues, and Principal.

First, beyond routine implementers of teaching, the teachers are professional knowledge builders who explore new visions and possibilities of teaching and test new and adaptive teaching designs for continual improvement. Their visions of teaching concentrate on whole child development, including intellectual curiosity, creative problem solving, caring, respect, collective responsibility, and openmindedness. They see knowledge building pedagogy and technology as supporting their visions. Since there are no given classroom procedures for achieving these high-order learning outcomes, the teachers have to work as professional knowledge builders to develop and improve specific designs in light of principles of knowledge building. In this undergoing process (Gee, 2001), they are empowered to engage in constant interpretation and reinterpretation (Beijaard et al., 2004) of who they are as knowledge building teachers. They are deeply aware that who they are as teachers constantly changes because of their strong sense that they need to become educators who help children to engage in increasingly productive knowledge building. This mindset allows the teachers to develop an adaptive approach that demonstrates itself in readiness and openness to change existing classroom arrangements and processes and test new and improved strategies, including new ways to use technology. Their identity as vision-directed professional knowledge builders is consistent with and supported by their knowledge building practices, which require high-level dynamics and adaptation in classroom work. The teachers reflect on who they are and what they do in the context of knowledge building pedagogy, which in itself demands that teachers build knowledge about their pedagogy and develop it.

A related aspect of the teachers' identity has to do with how they position themselves in relation to the contextual challenges and constraints of their work (Beijaard et al., 2004, Gee, 2001; Rodgers \& Scott, 2008; Varelas et al., 2005). The literature suggests that teachers often see obstacles and contextual constraints as preventing them from innovation and change. The teachers in this study actively identify and 
address challenges instead of avoiding them. They identify themselves as problem solvers and barrierbreakers who continuously develop adaptive strategies to make knowledge building possible and productive. They approach obstacles in a proactive way so they can solve the problems with their colleagues and students, transform obstacles into innovative ideas and opportunities, and implement and improve knowledge building under new conditions. Such a proactive stance is an important part of the teachers' identity, allowing them to resolve dilemmas and make decisions to sustain student-centred inquiry (see also, Enyedy et al., 2005).

Another important characteristic of the professional identity that the focal teachers display is reflected in their social relationships with others (Beijaard et al., 2004; Gee, 2001; Sfard \& Prusak, 2005). Through forming relationships with students, peer teachers, and administrators, the teachers brought forth multiple identities (Gee, 2001), or aspects of oneself (Rodgers \& Scott, 2008), that are connected to "their performances in society" (Gee, 2001, p. 99). First, the teachers' relationships with students constitute their identity. Their understanding of themselves as a certain kind of professionals deeply involves students (Beauchamp \& Thomas, 2009) and forming certain kinds of relationships with them. Different from traditional authoritative roles, they identify themselves as co-learners with their students in a community of knowledge builders. This results in a symmetrical relationship with students in which students assume highlevel agency for continually evolving knowledge building. This relationship is aligned with the way the teachers approach classroom discussions in both face-to-face and online settings through Knowledge Forum, not as teacher-planned conversations but students-driven, spontaneous, and co-improvised conversations driven by students' authentic questions and ideas. Such a symmetrical relationship has been evidenced to some extent in research on inquiry-oriented teachers; however, this symmetry was either not always sustained (Enyedy et al., 2005) or was incidental (Crawford, 2000; Tabak \& Baumgartner, 2004).

Yet another essential attribute of teachers' identity is deeply intertwined with the kind of relationships they form with other teachers and with their Principal. Their sense of belonging to a professional community, as the teachers express in their reflective narratives, substantially strengthens their bold vision of innovative and adventurous teaching (Cohen, 1989). In the collaborative team, devoted to inquiry and improvement of teaching, the teachers also display a hybrid identity (Bereiter, 2002) by describing themselves not only as teachers but also researchers who research their own practice, in cooperation with other teachers and researchers, to continually advance their pedagogical insights and strategies. Increasingly effective knowledge building practice is what results from this multidimensional identity that involves co-developing better understanding and designs of classroom practices, supporting each other to solve problems and take risks, sharing successes and failures based on formal and informal data collection, and challenging one another in an atmosphere of mutual respect and sharing.

Supporting their exploration and improvement of classroom practices to facilitate knowledge building, the teachers further develop a democratic and professionally oriented relationship with their Principal. Underpinning this relationship is a mutual understanding that continual innovation and experimentation are necessary for educational improvement and that teaching needs to be coupled with research. These teachers treat the Principal both as a leader who is devoted to the school and as an educator who can always share ideas and expertise and engage in professional conversation with teachers. This type of relationship results in teachers' seeing themselves as empowered to pursue teaching according to their vision, take risks to experiment with innovative approaches, and collaborate and share with their Principal and other colleagues about advances and challenges. This kind of democratic relationship with the Principal and its direct connection to how teachers perceive and identify themselves has never been evidenced in literature on teacher identity.

These various aspects of teacher identity appear to be deeply connected to one another, depicting a coherent image of the teacher's self in the contexts of inquiry-based, knowledge building classrooms. The teachers' identity as vision-driven professional knowledge builders who continually improve classroom practice is supported by their role as problem-solvers and barrier-breakers to address contextual challenges and constraints and by their relationships with their students, peers, and Principal. They co-construct their 
identity through engagement with their students, peers, and Principal in transformative cultural practices (Smagorinky et al., 2004), which focus on collaborative knowledge building. Through co-engaging with their students in knowledge building and reflecting on such experiences, they notice and are impressed by the deep ideas and active thinking of their students, which further reinforce their trust in student potential and agency and help the teachers to envision new possibilities to further engage students' responsibility through improved classroom designs. Through ongoing dialogue at weekly meetings that focus on knowledge building progress, strategies, and challenges, the teachers support and acknowledge one another as professional knowledge builders, problem solvers, and co-learners. These identities are further empowered by the democratic relationship with the Principal who facilitates a supportive school culture for sustained innovation (Zhang et al., 2011). With these important characteristics of who they are and what they strive for, the teachers are able to be persistent and productive in implementing and improving knowledge building practices and addressing various challenges on an ongoing basis. At the point of this study, the teachers were still searching for effective ways to implement knowledge building in mathematics, drawing on a set of strategies tested.

\section{Implications}

In conclusion, this study of the three teachers who have been engaging in knowledge building pedagogy for continual innovation contributes to understanding the new professional identity of inquirybased teachers in computer-supported collaborative classrooms. The teachers' identity is multifaceted, as vision-driven professional knowledge builders, problem solvers, co-learners with students, and innovative collaborators with colleagues. Such identity is co-constructed through sustained engagement in the pedagogical practice of knowledge building that both the teachers and administrators value as beneficial for children' development as well as the constant improvement of teaching in spite of challenges. It is further shaped and sustained through the symmetrical relationship with students, innovative collaboration with other teachers, and the democratic relationship with the Principal.

Teacher development initiatives to support authentic inquiry practices and educational innovations need to nurture the new aspects of teacher identity identified in this study. The best form of professional development is probably to create collaborative, professional knowledge building communities among teachers in which such important new identities are valued and enacted, as featured in this study. In the field of computer-supported collaborative learning, researchers are developing innovative efforts to create reflective communities and professional networks among teachers so they can develop the capacity to implement collaborative knowledge building among their students (Chan, 2011; Laferrière, Breuleux, Allaire, Hamel, Law, et al., in press). A primary focus of such communities is on engaging teachers in collaborative sharing of pedagogical understandings and co-creation of classroom designs (Voogt, Laferrière, Breuleux, Itow, Hickey, \& McKenney, 2015). In light of the findings of this study, researchers may additionally test systematic efforts to help teachers reflect on and transform their professional identity, including their vision of teaching, stance toward classroom practice, and relationships with their students, colleagues, and administrators. Such identity-focused reflection may be designed using a narrative approach (Sfard \& Prusak, 2005) to engage teachers in collaborative story telling about who they are now and who they hope to become professionally, always in relation to their context that includes both the practice and the types of relationships they build with others. Comparing the stories among different teachers, including their Principal, and reflecting on the stories in relation to the principles of collaborative inquiry and knowledge building may create valuable opportunities for teachers to transform their identity and practices. We are interested to test this possibility in our future studies.

As a potential shortcoming of this study, the findings were generated based on the analysis of a small sample of teachers who have been implementing knowledge building as a specific model of inquiry-based 
pedagogy. The results are limited to understanding teacher identity in the contexts of sustained, open-ended inquiry in which the teachers are not charged to follow a set of tasks and procedural steps designed by researchers and curriculum developers, but to design, improvise, and deepen the inquiry process as it unfolds, based on interactive input from students. Future research needs to look at other innovative groups of teachers, at different stages of their career, to see similarities and differences in how they understand and perform their identities, and conduct deeper analyses of teacher identity performed in their classroom practices.

\section{Keypoints}

- Bringing computer-supported collaborative knowledge building into classrooms requires new professional identities of teachers.

- The new professional identities involve teachers as vision-driven professional knowledge builders; as problem-solvers to address contextual challenges; as co-learners with students; and as innovative collaborators with colleagues.

- Teacher development efforts to support authentic inquiry and knowledge building need to nurture these new aspects of teacher identity. The best form of professional development is probably to create collaborative, professional knowledge building communities among teachers in which such important new identities are valued, enacted, and reflected upon.

\section{Acknowledgments}

This research was supported by the National Science Foundation (IIS \#1441479). Any opinions expressed in this paper are those of the authors and do not necessarily reflect the views of the National Science Foundation. Part of the findings has been presented at the International Conference on Computer Supported Collaborative Learning (CSCL 2015, Gothenburg, Sweden). The authors would like to thank the teachers, Principal, and students of the Dr. Eric Jackman Institute of Child Study of the University of Toronto for the insights, accomplishments, and research opportunities enabled by their work.

\section{References}

Antonek, J. L., McCormick, D. E., \& Donato, R. (1997). The student teacher portfolio as autobiography: Developing a professional identity. The Modern Language Journal, 81(1), 15-27. DOI: $10.2307 / 329158$

Barbour, R. (2001). Checklists for improving rigour in qualitative research: a case of the tail wagging the dog? British Medical Journal, 322, 1115-1117. DOI: http://dx.doi.org/10.1136/bmj.322.7294.1115

Barry, C. A., Britten, N., Barber, N., Bradley, C., \& Stevenson, F. (1999). Using reflexivity to optimize teamwork in qualitative research. Qualitative Health Research, (9)1, 26-44.

Beauchamp, C., \& Thomas, L. (2009). Understanding teacher identity: an overview of issues in the literature and implications for teacher education. Cambridge Journal of Education, 39(2), 175-189. DOI: $10.1080 / 03057640902902252$

Beijaard, D., Meijer, P. C., \& Verloop, N. (2004). Reconsidering research on teachers' professional identity. Teaching \& Teacher Education: An International Journal of Research and Studies, 20(2), 107-128. DOI:10.1016/j.tate.2003.07.001 
Belland, B. R., Glazewski, K. D., \& Richardson, J. C. (2008). A scaffolding framework to support the construction of evidence-based arguments among middle school students. Educational Technology Research and Development, 56(4), 401-422. DOI:10.1007/s11423-007-9074-1

Bereiter, C. (2002). Education and mind in the knowledge age. Mahwah, NJ: Erlbaum.

Bransford, J., Darling-Hammond, L., \& LePage, P. (2005). Introduction. In L. Darling-Hammond \& J. Bransford (Eds.), Preparing teachers for a changing world: What teachers should learn and be able to do (pp. 1-39). San Francisco, CA: Jossey-Bass.

Brooke, G. E. (1994). My personal journey toward professionalism. Young Children, 49(6), 69-71.

Brush, T., \& Saye, J. (2000). Implementation and evaluation of a student-centered learning unit: A case study. Educational Technology Research and Development, 48(3),79-100.

Chan, C. K. K. (2011). Bridging research and practice: Implementing and sustaining knowledge building in Hong Kong classrooms. International Journal of Computer-Supported Collaborative Learning, 6(2), 147-186. DOI:10.1007/s11412-011-9121-0

Clandinin, D. J. \& Huber, M. (2005). Shifting stories to live by: interweaving the personal and the professional in teachers' lives. In D. Beijaard, P. Meijer, G. Morine-Dershimer, \& H. Tillema (Eds.), Teacher professional development in changing conditions (pp. 43-61). Dordrecht: Springer.

Coffey, A., \& Aktinson, P. (1996). Making sense of qualitative data: Complementary research strategies. Thousand Oaks, CA: Sage.

Cohen, D. K. (1989). Teaching practice: Plus que ca change....In P. W. Jackson (Ed.), Contributing to educational change: Perspectives on research and practice (pp. 27-84). Berkeley, CA: McCutchan.

Coldron, J., \& Smith, R. (1999). Active location in teachers' construction of their professional identities. Journal of Curriculum Studies, 31(6), 711-726. DOI:10.1080/002202799182954

Connelly, F. M., \& Clandinin, D. J. (2000). Shaping a professional identity: Stories of education practice. London, ON: Althouse Press.

Coyne, I., \& Cowley, S. (2006). Using grounded theory to research parent participation. Journal of Research in Nursing, 11(6), 501-515. DOI: 10.1177/1744987106065831

Crawford, B. A. (2000). Embracing the essence of inquiry: New roles for science teachers. Journal of Research in Science Teaching, 37, 916-937. DOI: 10.1002/1098-2736(200011)37:9<916::AIDTEA4 $>3.0 . \mathrm{CO} ; 2-2$

Crawford, V. M., Schlager, M., Toyama, Y., Riel, M., \& Vahey, P. (2005, April). Characterizing adaptive expertise in science teaching: Report on a laboratory study of teacher reasoning. Paper presented at the Annual Meeting of the American Educational Research Association, Montreal, Canada.

Davis, E. (2006). Characterizing productive reflection among preservice elementary teachers: Seeing what matters. Teaching and Teacher Education, 22, 281-301. DOI:10.1016/j.tate.2005.11.005

Denzin, N. K. (2002). The interpretive process. In M. Huberman \& M. B. Miles (Eds.), The qualitative researcher's companion (pp. 340-368). Thousand Oaks, CA: Sage.

Dillabough, J. A. (1999). Gender politics and conceptions of the modern teacher: Women, identity and professionalism. British Journal of Sociology of Education, 20(3), 373-394.

Duffy, G. (2005). Metacognition and the development of reading teachers. In C. Block, S. Israel, K. Kinnucan-Welsch, \& K. Bauserman (Eds.), Metacognition and literacy learning (pp. 299-314). Mahwah, NJ: Lawrence Erlbaum.

Dunne, C. (2011). The place of the literature review in grounded theory research. International Journal of Social Research Methodology, 14(2), 111-124. DOI: 10.1080/13645579.2010.494930

Enyedy, N., Goldberg, J, \& Welsh, K. M. (2005). Complex dilemmas of identity and practice. Science Education, 90(1), 68-93. DOI 10.1002/sce.20096

Fairbanks, C. M., Duffy, G. G., Faircloth, B. S., Ye, H., Levin, B., Rohr, J., \& Stein, C. (2010). Beyond knowledge: Exploring why some teachers are more thoughtfully adaptive than others. Journal of Teacher Education, 61(1/2), 161-171. DOI: 10.1177/0022487109347874

Fishman, B. J., Davis, E.A., \& Chan, C. K.K. (2014). A learning sciences perspective on teacher learning research. In R. K. Sawyer (Ed.), Cambridge Handbook of the Learning Sciences (2nd ed., pp.750-769). New York: Cambridge University Press. 
Gee, J. P. (2001). Identity as an analytic lens for research in education. In W. G. Secada (Ed.), Review of research in education, Vol. 25 (pp. 99-125). Washington, DC: American Educational Research Association.

Gee, J., \& Crawford, V. (1998). Two kinds of teenagers: Language, identity, and social class. In D. Alvermann, K. Hinchman, D. Moore, S. Phelps, \& D. Waff (Eds.), Reconceptualizing the literacies in adolescents' lives (pp. 225-245). Mahwah, NJ: Erlbaum.

Henwood, K., \& Pidgeon, N. (2006). Grounded theory. In G. M. Breakwell, S. Hammond, C. Fife-Shaw, \& J. A. Smith (Eds.), Research methods in psychology (3rd ed., pp. 342-365). Thousand Oaks, CA: Sage.

Hjalmarson, M. A., \& Diefes-Dux, H. (2008). Teacher as designer: A framework for teacher analysis of mathematical model-eliciting activities. Interdisciplinary Journal of Problem-Based Learning, 2(1), 57-78. DOI:10.7771/1541-5015.1051

Hmelo-Silver, C. E., \& Burrows, H. S. (2006). Goals and strategies of a problem-based learning facilitator. Interdisciplinary Journal of Problem-Based Learning, 1(1), 21-39. DOI:10.7771/1541-5015.1004

Holland, D., Lachicotte, W., Skinner, D., \& Caine, C. (1998). Identity and agency in cultural worlds. Cambridge, MA: Harvard University Press.

Laferrière, T., Breuleux, A., Allaire, S., Hamel, C., Law, N., Montané, M., Hernandez, O., Turcotte, S., \& Scardamalia, M. (in press). The Knowledge Building International Project (KBIP): Scaling up Professional Development for Effective Uses of Collaborative Technologies. In C.-K. Looi \& L. W. Teh (Eds.), Scaling Educational Innovations. New York: Springer.

Little, J. W., Lampert, M., Graziani, F., Borko, H., Clark, K. K., \& Wong, N. (2007, April). Conceptualizing and investigating the practice of facilitation in content-oriented teacher professional development. Symposium conducted at the annual meeting of the American Educational Research Association, Chicago.

Lunn, S., \& Solomon, J. (2000). Primary teachers' thinking about the English national curriculum for science: Autobiographies, warrants, and autonomy. Journal of Research in Science Teaching, 37(10), 1043-1056. DOI: 10.1002/1098-2736(200012)37:10<1043::AID-TEA2>3.0.CO;2-S

Mason, J. (1996). Qualitative researching. London: Sage Ltd.

Mayer, D. (1999) Building teaching identities: Implications for pre-service teacher education. Paper presented to the Australian Association for Research in Education, Melbourne.

McCann, T., \& Clark, E. (2003). Grounded theory in nursing research: Part 1 - Methodology. Nurse Researcher, 11(2), 7-18.

McGhee, G., Marland, G. R., \& Atkinson, J. (2007). Grounded theory research: Literature reviewing and reflexivity. Journal of Advanced Nursing, 60(3), 334-342. DOI: 10.1111/j.1365-2648.2007.04436.x

McMenamin, I. (2006). Process and text: Teaching students to review the literature. PS: Political Science and Politics, 39(1), 133-135.

Mills, H. (2014). Learning for real. Portsmouth, NH: Heinemann.

National Research Council (2012). A framework for K-12 science education: Practices, crosscutting concepts, and core Ideas. Washington, DC: The National Academies Press.

Olsen, B. (2008). Introducing teacher identity and this volume. Teacher Education Quarterly, 35(3), 3-6.

Palmer, P. J. (1997). The courage to teach: Exploring the inner landscape of a teacher's life. San Francisco, CA: Jossey-Bass Publishers.

Parkison, P. (2008). Space for performing teacher identity: Through the lens of Kafka and Hegel. Teachers and Teaching: Theory and Practice, 14(1), 51-60. DOI:10.1080/13540600701837640

Rodgers, C. R., \& Scott, K. H. (2008). Development of the personal self and professional identity in learning to teach. In M. Cochran-Smith \& S. Feiman-Nemser (Eds.), Handbook of Research in Teacher Education (pp. 732-755). Mahway, NJ: Lawrence. Earlbaum.

Schwandt, T. (1997). Qualitative inquiry: A dictionary of terms. Thousand Oaks, CA: Sage.

Sfard, A., \& Prusak, A. (2005). Telling identities: In search of an analytic tool for investigating learning as a culturally shaped activity. Educational Researcher, 34(4), 14-22. DOI: 10.3102/0013189X034004014

Sawyer, R. (2004). Creative teaching: Collaborative improvisation. Educational Leadership, 33, 12-20. DOI: 10.3102/0013189X033002012 
Scardamalia, M., \& Bereiter, C. (2006). Knowledge building: Theory, pedagogy, and technology. In R. K. Sawyer (Ed.), Cambridge handbook of the learning sciences (pp. 97-115). New York: Cambridge University Press.

Smagorinsky, P., Cook, L. S., Moore, C., Jackson, A.Y., \& Fry, P. G. (2004). Tensions in learning to teach: accommodations and the development of a teaching identity. Journal of Teacher Education, 55(1), 8 24. DOI: $10.1177 / 0022487103260067$

Strauss, A., \& Corbin, J. (1998). Basics of qualitative research: Techniques and procedures for developing grounded theory (2nd ed.). Newbury Park, CA: Sage.

Tabak, I., \& Baumgartner, E. (2004). The teacher as partner: Exploring participant structures, symmetry, and identity work in scaffolding. Cognition and Instruction, 22(4), 393-429.

Urquhart, C. (2007). The evolving nature of grounded theory method: The case of the information systems discipline. In A. Bryant \& K. Charmaz (Eds.), The SAGE handbook of grounded theory (pp. 339-360). London: Sage.

Varelas, M., House, R., \& Wenzel, S. (2005). Beginning teachers immersed into science: Scientist and science teacher identities. Science Education, 89(3), 492-516. DOI: 10.1002/sce.20047

Volkmann, M. J., \& Anderson, M. A. (1998). Creating professional identity: Dilemmas and metaphors of a first-year chemistry teacher. Science Education, 82(3), 293-310.

Voogt, J., Laferrie're, T., Breuleux, A., Itow, R. C., Hickey, D. T., \& McKenney, S. (2015). Collaborative design as a form of professional development. Instructional Science, 43, 259-282. DOI: 10.1002/(SICI)1098-237X(199806)82:3<293::AID-SCE1>3.0.CO;2-7

Zhang, J., Hong, H.-Y., Scardamalia, M., Teo, C. L., \& Morley, E. A. (2011). Sustaining knowledge building as a principle-based innovation at an elementary school. Journal of the Learning Sciences, 20(2), 262-307. DOI: 10.1080/10508406.2011.528317

Zhang, J., \& Messina, R. (2010). Collaborative productivity as self-sustaining processes in a Grade 4 knowledge building community. In K. Gomez, J. Radinsky, \& L. Lyons (Eds.), Proceedings of the 9th International Conference of the Learning Sciences (pp. 49-56). Chicago, IL: International Society of the Learning Sciences.

Zhang, J., Scardamalia, M., Reeve, R., \& Messina, R. (2009). Designs for collective cognitive responsibility in knowledge building communities. Journal of the Learning Sciences, 18, 7-44. DOI:10.1080/10508400802581676

Zhang, J, \& Sun, Y. (2011). Reading for idea advancement in a grade 4 knowledge building community. Instructional Science, 39(4), 429-452. DOI: 10.1007/s11251-010-9135-4 